\title{
Study on the Training Mode of Innovative Talents in Tourism Management Major in Higher Vocational Education
}

\author{
Jianlin Ma \\ Chongqing Business Vocational College
}

\begin{abstract}
Keywords: Tourism teaching; Innovative talents; Countermeasures and suggestions
\end{abstract}
\begin{abstract}
Higher vocational colleges are important part in China's higher education system, which is mainly for the cultivation of talents, and it has a certain professional knowledge base and practical ability. At present, with the rapid development of the tourism industry, and the rapid development of the demand for talent has become increasingly prominent, at the same time, the problems of Tourism Management in higher vocational colleges are emerging. Therefore, this paper mainly discusses the problems and patterns of tourism talents training in Tourism Management Major in higher vocational colleges.

In recent years, due to the increasing enrollment of undergraduate colleges and universities, the enrollment rate of higher vocational colleges has been declining year by year. At the same time, backwardness of vocational training model has become more and more, the Ministry of education and local colleges are actively promoting the curriculum reform of higher vocational colleges, hoping that through the reform to cultivate more innovative talents to adapt to social development. This paper puts forward a discussion on the training mode of Tourism Management Major in Higher Vocational colleges.
\end{abstract}

\section{The Basic Concept and Characteristics of Innovative Talents}

"Innovative talents" mainly refers to those who have all kinds of knowledge, with innovative thinking to look at and solve various problems, but also has a sense of innovative ability who can be called comprehensive talent. Generally speaking, innovative talents have the following characteristics:

(1) The comprehensive knowledge system is higher. Innovative talents not only have a solid foundation of knowledge, but also have a wide range of knowledge, only in this way, they can grasp the latest professional dynamic in any field in order to better stimulate their innovative thinking.

(2) Strong indomitable willpower. With the rapid change and development of the society, the demand for innovation is also increasing. But innovation is not a short duration of time thing, it not only need high-quality personnel, but also take a long time to try and verify again. This determines that people need to have a strong willpower and never retreat to make innovation.

(3) Good learning quality. Because the innovative talents should have a comprehensive knowledge system, which requires innovative talents must have a good learning quality that can quickly and accurately learn the latest knowledge and professional dynamic.

(4) Keen observation. Innovation activities often requires people to have a keen observation to find things behind the law and the inevitable link, and get an important inspiration for innovation activities, so as to lay a good foundation for innovation activities.

\section{Analysis on the Current Situation and Problems of Tourism Management Major in Higher Vocational Education}

At present, in order to adapt to the development of tourism, general China's Higher Vocational Colleges set tourism management professional, for many years, it has played a certain role in promoting for the development of China's tourism. However, with the progress and development of society, the teaching mode of tourism management specialty is becoming more and more unsuitable for the demand of modern tourism.

Backward of Teaching Mode. At present, the classroom teaching of Tourism Management in 
higher vocational colleges uses main indoctrination mode, namely the use of a single teaching method, those that teach knowledge with the backwardness to tourism management students, this teaching method does not reflect the students' subject consciousness, which greatly hinder the students' innovation enthusiasm that is not conducive to the cultivation of innovative talents. Because the master to the basic knowledge firmly need to cultivate innovative talents of tourism management for students, but also continuously according to the actual situation to fully understand and grasp the dynamic development of tourism management, so as to realize the cultivation of innovative talents of professional tourism management.

Lack of Innovation Opportunities. The way of teacher of Higher vocational colleges teaching of tourism management majors are according to the textbook knowledge in the classroom, and the method of classroom teaching is almost the main teaching mode of tourism management major. This is mode that the students are passive to accept a variety of theoretical knowledge, and the lack of theoretical verification and practical aspects of the practice. The cultivation of tourism management innovation talents not only need the basic theoretical knowledge, but also need to carry on the continuous practice, and constantly innovate in practice. At present, the teaching mode of tourism management innovation talents in higher vocational colleges is not conducive to provide innovative opportunities for the students.

Dislocation on Teaching Subject. The teacher as the subject of classroom teaching is still the common phenomenon of Tourism Management Specialty in higher vocational colleges,in this teaching model, the relationship between teachers and students has not very good communication, students' ideas cannot find expression in exports, thereby it affects the students' enthusiasm for teaching activities, but also to lose interest in innovation activities. Because of the rapid development of the tourism industry today, innovative talents in the field of tourism has put forward higher requirements, which requires the tourism innovative talents should have the initiative and enthusiasm which can quickly detect and found in the field of tourism opportunities with development opportunities and create the field of tourism. Therefore, higher vocational college tourism management professional innovation in the process of teaching the subject of the dislocation is not only detrimental to the development of the professional, but also seriously affect the effectiveness of personnel training.

Lack of Innovation Environment. Environment plays a very important role in the individual learning process. At present, both undergraduate and vocational colleges are lack of innovation environment. This leads to the cultivation of professional talents in higher vocational education, which is not conducive to the development of innovative work in tourism management.

\section{Relevant Countermeasures and Suggestions}

Innovative Classroom Teaching Mode. (1) The combination of theory and practice. In the past, tourism management professionals in higher vocational colleges often only pay attention to theory, and ignore the practice. Therefore, in the future training should put theory and practice together in which not only let the students master the tourism management professional knowledge, but also to enable students to apply the professional knowledge for the actual work of tourism management.

(2) pro - Test method. Based on the traditional classroom teaching mode, teachers can take various forms of the site teaching and simulation teaching methods to guide students to better understand and master the knowledge of tourism management major and the present development situation of tourism. For example, in the daily teaching, teachers can make students to get into the field of tourism typical case with analysis and discussion, excitation and multi angle of view are needed to encourage this process in order to practice, which also can lead the students to carry out various forms, through the practice of learning realize students can master and understand the tourism management process.

(3) Teach students in accordance with their aptitude. For the innovative talents of tourism management, Higher vocational colleges not only need to teach the basic professional knowledge, but also should be based on the characteristics of different students, develop in different ways to stimulate students' interest in tourism management, so that they actively participate in the theory 
and practice of teaching, and promote the cultivation of innovative thinking and innovative ability.

(4) Open teaching mode. For the cultivation of innovative talents, it should be in the teaching of theoretical and practical knowledge, but also to broaden students' horizon and vision. To this end, it can be held regularly in the forefront of the field of Tourism Forum, inviting to teach the latest tourism related to the latest tourism theory and tourism development trends. In addition, students should be encouraged to actively participate in social practice, and constantly deepen and consolidate their basic knowledge, and to better cultivate their innovative ability in practice. The higher vocational colleges create a good academic atmosphere and innovative environment for the students, which have important significance for the cultivation of innovative talents in tourism management.

Constantly enrich the Professional Content of the Present Stage. At present, the teaching content of Higher Vocational Colleges in our country has been in use of the old teaching materials, the training of talents cannot adapt to the rapid development of modern tourism. Therefore, the teaching content should be existing comprehensive diagnosis, excluding the teaching content to adapt to the development of the times, at the same time, according to the development of modern tourism and tourism market, to improve the teaching content of tourism management specialty. For example, it can be properly brought into the tourism market analysis and national tourism culture teaching model, so the students of tourism management major has more abundant and broad professional knowledge from professional knowledge to promote their innovation practice.

Efforts to Build Innovative Educational Power. (1) Introduce innovative teaching talents. That is to construct the innovative education power to guide the students in the learning process. Therefore, it should develop and introduce a variety of incentives to attract and introduce such as tourism and planning, e-commerce and other interdisciplinary doctoral school and other innovative teaching talents in higher vocational colleges, strengthening the teaching of Higher Vocational Colleges in power at the same time, it also brings new thinking and content for Tourism Management Teaching in higher vocational colleges. At the same time, preferential policies to attract those with tourism management experience of enterprises high-end talent to the school teaching, it can make students more profound understanding and exposure to the practice of tourism management content, but also can combine the theory and practice, which is conducive to the cultivation of innovative talents of tourism management major.

(2) It should also strengthen the construction of the existing teaching staff in Colleges and universities. Continue to encourage and support teachers in the school to study or getting training to improve their teaching ability, which can make the existing of school teaching staff turnover study or on-the-job training helping students' stimulate innovative thinking mode during teaching. In addition, it can also actively cooperate with tourism enterprises or Tourism Bureau, the school sent the backbone of the teaching force attachment to exercise, cultivate teachers' innovative thinking in the practice teaching in the future to change the teaching way with using scientific teaching methods to cultivate students' innovation ability.

Creating the Atmosphere for Students' Innovative Learning. The quality of learning atmosphere for tourism management professional students can quickly grasp the professional knowledge of the major. In the cultivation of innovative talents in higher vocational colleges, a good innovative learning environment can greatly improve the efficiency of learning, but also inspire and encourage students to carry out innovation activities. For example, it can set up an innovative role model to drive the enthusiasm of other students, and through the example of the drive to enable students to quickly grasp the basic knowledge of tourism professionals. In addition, higher vocational colleges should pay attention to tourism enterprise cooperation to provide a practical platform for students where students can continuously consolidate the theory, and apply the theory to practice improving the practice ability for students.

\section{Conclusion}

At present, to cultivate innovative talents to adapt to the needs of the rapid development of the tourism industry, the Tourism Management Major in Higher Vocational Colleges must continue to 
change the mode of education, the education concept and content in order to eliminate those obstacles which is not conducive to the cultivation of innovative talents, and through creating innovative atmosphere and encourage students from various aspects to provide a good environment and lay a solid foundation for the cultivation of innovative talents of tourism management major.

\section{References}

[1] Ray rong. Later set up innovative talent training mode in the major of higher vocational tourism management $[\mathrm{J}]$. Journal of human institute of science and technology, and practices of 2013:102-104.

[2] xiu-yu xu. Tourism under the background of the new normal higher vocational tourism professional personnel training mode of innovative way research [J]. Journal of space-time, 2016,: 30-33.

[3] GuanShuGuang. Analyses the modern commercial space display design [J]. Journal of beauty and age. 2007 (9)

[4] Qiu Yu [3]. The design of commercial space program [J]. Journal of Anhui literature (second half). 2007 (12)

[5] Our fan. When city met art expression in shallow theory of transparency in commercial space [J]. Journal of Shanghai business. 2009 (05)

[6] Yuan Jincheng Luo Chao, Zhu Xiang. Green exhibition in the application of modern commercial space research in China [J]. Journal of art research. 2010 (04) 